

\title{
Hearing non-neutral: Listening practices and the construction of societal consensus in hybrid election campaign interviews
}

\author{
Argyro Kantara \\ Cardiff University, UK
}

\begin{abstract}
Ekström and Kroon Lundell (2009), Ekström (2011) and Hutchby (2011a, 2011b) refer to hybridity in political news interviews as the mix of activities or the systematic shifting between speech exchange systems otherwise associated with non-interview settings. In their examination of journalists' mixed interactional activities, both Hutchby and Ekström discuss how hybridity is explored as an interactional resource to question politicians and/or create an argumentative environment, breaching the neutralistic role of the broadcast news journalist. In this paper I examine instances of journalists' breaching neutralism not through their hybrid questioning practices but through their listening practices (Norrick, 2010) in one-on-one interviews conducted during the 2012 Greek general election campaigns. In my data, journalists use hybrid listening practices to co-produce politicians' arguments and to answer their own questions. Findings indicate that journalists' hybrid listening practices provide political actors with new ways to mainstream and appropriate their manifestos to the public.
\end{abstract}

\section{Keywords}

hybridity, election campaign interviews, listening practices, reactive tokens, neutralism

\section{Corresponding author}

Argyro Kantara, Centre for Language and Communication Research, School of English, Communication and Philosophy, Cardiff University, John Percival Building, Colum Drive, Cardiff, CF10 3EU, United Kingdom

Email: KantaraA@cardiff.ac.uk 


\section{Introduction}

Previous research on hybridity in broadcast political news interviews in the Swedish context (Ekström and Kroon Lundell, 2009; Ekström, 2011) and in the Anglo-Saxon context (Hutchby, 2011a, 2011b), has defined the phenomenon as the systematic shifting between speech exchange systems otherwise associated with non-interview settings. In particular, Hutchby (2011a, 2011b) discusses hybridity in the context of the hybrid political news show, a broadcast news genre that combines features of the neutralism ${ }^{1}$ of broadcast interviews and argumentative/confrontational discourse. Within this hybrid news interview genre, the journalist occupies the role of the sociopolitical advocate and, by means of direct tribuneship, (see Hutchby, 2016, this issue), a highly opinionated argumentative discourse is created. In this way, the journalist not only invokes 'alignment-laden sections of the population' (Hutchby, 2016: xx) but also moves away from the neutralistic stance.

In a similar vein, Ekström and Kroon Lundell (2009) and Ekström (2011), discuss hybridity as a mix of different (frames) of activities (Goffman, 1974; Levinson, 1992; Linell, 2011). In particular, Ekström (2011: 151-152) demonstrates how the mix of discursive roles and resources available to the interviewer in the hybrid format of talk in a political talk show interview enables the interviewer to use them partly as an adversarial resource. And here lies the similarity but also the difference with Hutchby's discussion of hybridity.

While for both Hutchby and Ekström the mix of discourse roles and different (frames of) activities is used in the hybrid news interview as an adversarial resource, the discursive positions occupied by the interviewer and the resulting genre in the respective datasets examined is slightly different. In Hutchby's dataset, the use of unmitigated direct and personalised argumentative techniques by interviewers, frequent in mundane argument rather than in hard news interview (Hutchby, 2016), positions the journalist as a socio-political 


\section{Kantara}

advocate and marks the interviews analysed as being on the verge between an interview and an argument.

In Ekström's case study, hybrid frames of activities (i.e. humorous and serious political frames) are invoked and negotiated in three environments: (1) in the asking and answering of questions, (2) in relation to host reactions in third position inside the activity of interviewing and (3) in sequential frame shifts. They result in the creation of 'a programme which can reasonably be heard by the audience as simultaneously lively, spontaneous, funny, nasty, critical and adversarial' (2011: 151). In other words, both participants, by means of mixing frames of activities of ordinary conversation and accountability political interviews, create an interview genre that is on the verge between a friendly conversation (the 'feel good genre' of talk shows (Clayman and Heritage, 2002) and the 'high profile' accountability interview (Montgomery, 2007).

The way I understand and use hybridity in this paper follows broadly the way the aforementioned researchers have approached it, as the systematic shifting between speech exchange systems otherwise associated with non-interview settings. In other words, I understand hybridity as the mixture of activity types usually associated with accountability interviews and 'feel good' interviews. What differentiates the way I examine hybridity though is that I do not examine it as an (adversarial) questioning practice by journalists but as a listening practice (as discussed by Norrick, 2010). Broadly, that is the use of interviewer feedback activities (e.g. use of reactive tokens) in third position during the interview activity (see the next section for a detailed discussion of listening practices).

Evaluative responses and response tokens in third position are not typical of news interviews as they suggest that the journalist is the primary recipient of the answer and not a neutral interrogator asking questions on behalf of the audience (Heritage, 1985, Clayman, 2007). For this reason, absence of these ordinary conversation features is typical of news 
interviews, where the preference structure, in contrast to ordinary conversation, is for the journalist to ask another question in the turn following an interviewee answer (Ekström, 2011: 144). As already mentioned, contrary to the 'hard' news interviews preference structure, in the hybrid format of the radio talk show political interview examined by Ekström, reactions to interviewees' answers in third position are common and their function is manifold. They question what the interviewee is doing, playing with his/her identity, and highlight distinctions between the lay and the expert.

In the sections to follow I will review previous research on listening practices in televised (non-accountability) interviews and present my data and analytic approach, before examining how interviewers signal listenership and the uptake of information, how they prompt and aid the politicians, how the latter respond and what the potential impact of these hybrid practices for the election campaign interview genre and the overhearing audience might be.

\section{Data and analytic approach}

My dataset comprises 13 one-on-one televised interviews from the double 2012 Greek general elections campaign. The interviews are between all political party leaders whose parties won seats in the 2012 parliament and leading journalists of three private TV channels (ANT1, MEGA, SKAI) and the (then) public broadcast corporation (NET). The dataset comprises both long interviews (lasting approximately 40') broadcast during special preelection programmes and short interviews (lasting approximately 15') broadcast during evening (8 o'clock) news bulletins.

As Clayman and Romaniuk (2011: 15) claim, the election campaign interview, is a variant of the accountability interview (Montgomery, 2007). As they go on to claim, what differentiates election campaign from accountability interviews is that the former involve 


\section{Kantara}

only political candidates rather than current office holders and that the focus of the questions is different from questions in other political contexts. Although when journalists interview political candidates they rely on questioning resources that they use in other interviewing contexts, the focus of 'campaign' questions is on a range of substantive issues central to the pre-election arena: on knowledgeability, ideological positioning (political issue questions) and policy promises (promise-soliciting questions). A key theme emerging from their analysis is the dual import of question design in developing a public portrait of the candidate. For Clayman and Romaniuk (2011: 30),

[Q]questions matter not only for the responses they elicit, but also for the varying stances that they themselves exhibit toward the candidate. Even though these questions remain for the most part formally 'neutralistic' in being designed as interrogatives that ostensibly 'request information', they nonetheless convey information about the candidate in an embedded or implicit way. [...] All of this combines to treat the candidate as, for example, more or less knowledgeable, more or less centrist, more or less extreme.

Despite the fact that, as they point out, this portrayal is provisional as candidates during the interview can counter the identity proposed for them, the role of the questions asked, how they are being responded to and how the election campaign interview is conducted, are issues of paramount importance in terms of the knowledge created for the overhearing audience.

The interviews have been transcribed (see Appendix for the transcription conventions) and analysed qualitatively from a conversation analytic perspective and are presented in the original language, alongside my translation in English. The extracts presented in the subsequent sections involve three journalists working in private TV channels and four 
political party leaders from a wide spectrum of political parties, ranging from a right-wing populist party to a communist party.

\section{Previous research on listening practices in televised (non-accountability) interviews}

Norrick (2010) has described the listening practices of interviewers in US American television celebrity interviews, examining the listener activities mainly of Oprah Winfrey, Larry King and one example from Jay Leno. In his investigation of interviewer listening activities in the aforementioned shows he explored how interviewers signal listenership, emotional involvement, and the uptake of information, how they prompt, aid and act as a foil to interviewees and how these practices may affect the audience and the trajectory of the interview in progress (2010: 525).

In the television celebrity interviews examined, Norrick claims the interviewer listening practices move from activities that match listeners' practices in everyday conversation to strategies directed at guiding or entertaining the audience. In the dataset examined, interviewers go as far as to answer their own questions, engage in co-narration, and construct direct speech on behalf of their interviewees.

Although investigating different news interview formats, Norrick reaches similar conclusions to Ekström's in relation to whom the interviewer responses address: Ekström (2011: 153) claims that interviewer reactions 'draw audience attention to specific aspects of interviewer activities and identities', while Norrick (2010: 525) claims that 'interviewer responses may be directed primarily at the audience $[\ldots]$ and they can be more or less obtrusive or manipulative'. Furthermore, although not using the term hybrid talk, Norrick's conclusions are also similar to Ekström's in relation to the mix of participant roles, identities and activities in his dataset, the televised celebrity interviews. Apparently, the formal roles of 


\section{Kantara}

interviewer versus interviewee tend to resemble the ones in every day conversation between equals and the talk show hosts challenge their interviewees in different ways to make the interaction more vivid (Norrick, 2010:541).

A significant point of difference though between the two studies in relation to the function of interviewer reactions in third position, is that in Norrick's study, for entertainment purposes as he claims, interviewers interrupted the interviewee to propose a word or phrase, imposed their own interpretations of the interviewee narrative and/or answered their own questions.

\section{Response tokens, evaluative responses, reactive tokens}

As already discussed, Ekström (2011: 144) has indicated that in the integrated hybrid talk evident in the radio political talk show examined in his study, reactions to interviewee answers in third position were common. These reactions included evaluative responses and response tokens. Response tokens or continuers (Schegloff, 1982; Gardner, 1998, 2001 McCarthy, 2003) are common in everyday interaction and include neutral continuers like $u h$ huh, $\mathrm{mhm}$ and most occurrences of yeah. They indicate listener recipiency, and 'exhibit on the part of the producer an understanding that an extended turn of talk is underway by

another' (Schegloff, 1982:81). On the other hand, Norrick (2010), citing Goodwin (1986) and Heritage (1984: 299) notes that 'discourse markers like right, okay, some instances of yeah and interjections like wow, oh, really, signal either emotional involvement or register receipt of information indicating that their producer has undergone some kind of a change in his or her locally current state of knowledge, information, orientation or awareness' (Heritage, 1984:299). In that sense, the latter kind of listener responses may be regarded as evaluative responses indicating not only information uptake but personal involvement as well. As 
Norrick indicates, in the context of televised interviews, they are directed primarily at the interviewee.

Young and Lee (2004: 380-381) on the other hand, carrying out conversation analytic work in cross-cultural every day interaction, argue that all the above listener activities, are reactive tokens as they do not only indicate active listenership but they are conversational resources by which a listener co-constructs a speaker's turn at talk. They argue that in a speech exchange between two or more persons, talk in interaction is constructed by both participants, so the resulting talk in progress is a collaborative effort and not the product of a single speaker.

In their classification, reactive tokens include backchannels or continuers (Yngve, 1970; Schegloff, 1982) ( $\mathrm{mm} \mathrm{hm}$ ), acknowledgements (yeah), newsmakers (oh), change of activity tokens (alright), assessments (wow), (Maynard 1990; Gardner 1997, 2001) brief questions or repair, collaborative completions (Gardener 1997, 2001) and repetitions (Clancy, et al., 1996).

The last three listener activities resemble the rest of the types of listener responses identified by Norrick (2010: 529-537) in his dataset of celebrity talk show interviews. These include helping the interviewee respond (e.g. by providing a word or phrase), co-producing talk, providing background information, providing clarifications, proffering formulations of what their interviewees are getting at or proposing interpretations. As Norrick claims, apart from the first listener activity that addresses the interviewee, these activities address the audience.

Finally, Norrick (2010: 537-540) has identified two further interviewer listener practices that do not match any of the reactive tokens identified in the relevant literature but can be argued to be variations of the collaborative production type. These are: constructing 


\section{Kantara}

dialogue in interviews (interviewers answer their own questions) and providing a team performance.

In this paper I will use Young and Lee's term reactive tokens as I agree with their view that talk in interaction is co-produced by both participants. This is especially the case in broadcast talk where issues of professional conduct and getting information on behalf of the overhearing audience are of paramount importance, thus the use and type of reactive tokens used, determine to a certain extent the kind of broadcast talk produced.

In the following sections I will focus on two types of reactive tokens journalists in my dataset used to 'help' political party leaders respond: repetitions and collaborative completions (including journalists answering their own questions). These two types were not used in isolation, but rather in combination, together with other types of reactive tokens.

\section{Presentation of the data}

\section{Journalist answers his own question}

In the next two extracts two different journalists 'help' two different political party leaders respond by answering their own questions. They do so by latching before the politician finishes his evasive answer and provide the answer to the question they, themselves, asked. In both cases the politician accepts both the interactional move and its content and builds his next turn by elaborating on the answer given by the journalist.

Extract 1 This extract is taken from a long face to face interview (40' 12") between Antonis Samaras, the then leader of New Democracy (a center-right party) and Yiannis Pretenteris a leading journalist of a private TV channel (Mega TV). The interview was broadcast after the 8 o'clock evening news on April 92012 before the first round of elections and was one of the most widely viewed interviews of the 2012 double pre-election period. Six turns before the 
excerpt, the journalist asked the politician whether Troika had accepted the measures he was talking about. The politician evaded answering by attacking the government.

Video: $\quad 18: 20-18: 30$

Audio: 21:51-21:41

\begin{tabular}{|c|c|c|c|c|}
\hline 1 & $\Delta \eta \mu .:$ & 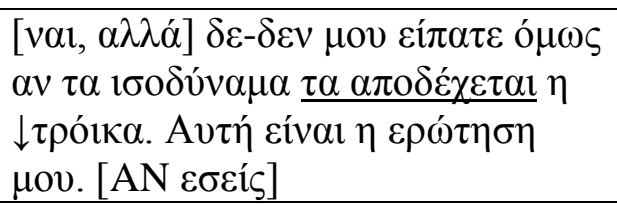 & Jour.: & $\begin{array}{l}\text { [yes, but] you have no-not told me } \\
\text { though whether } \downarrow \text { troika accepts the } \\
\text { equal fiscal measures. This is my } \\
\text { question. [IF you] }\end{array}$ \\
\hline 2 & Пол: & 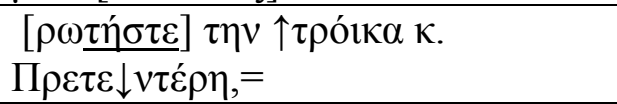 & Pol.: & [ask] $\uparrow$ troika Mr Prete $\downarrow$ nteris, $=$ \\
\hline 3 & $\Delta \eta \mu:$ & 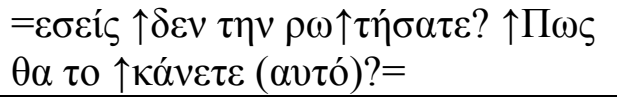 & Jour: & $\begin{array}{l}=\text { you have } \uparrow \text { not } \uparrow \text { asked them? } \\
\uparrow \text { How are you going to } \uparrow \text { do (this)?= }\end{array}$ \\
\hline 4 & Пол: & 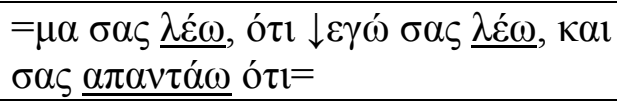 & Pol: & $\begin{array}{l}=\text { but } \mathrm{I} \text { am saying, that } \downarrow \mathrm{I} \text { am telling } \\
\text { you, and I am answering that }=\end{array}$ \\
\hline 5 & $\Delta \eta \mu:$ & $=\tau \alpha \downarrow \delta \varepsilon^{\prime} \chi \varepsilon \tau \alpha 1 .=$ & Jour: & $=$ they $\downarrow$ accept them. $=$ \\
\hline 6 & Под: & $=\pi \rho \varepsilon \dot{\varepsilon} \pi \varepsilon 1 \quad v \alpha \tau \alpha \alpha \pi \mathrm{o} \delta \varepsilon \uparrow \chi \tau \varepsilon \dot{1},=$ & Pol: & $=$ they have to accept them, $=$ \\
\hline 7 & $\Delta \eta \mu:$ & 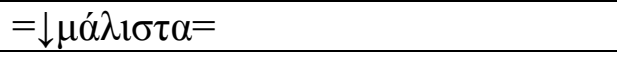 & Jour: & $=\downarrow$ right $=$ \\
\hline
\end{tabular}

In turn 1 the journalist 'sanctions interviewee resistance' in Romaniuk's (2013) terms, by means of explicitly stating what the politician has not done in his response: 'have not told me though'. This is followed by an almost verbatim repetition of the initial question 'whether Troika accepts the equal fiscal measures' and by explicitly referencing the initial question 'this is my question', a technique which further highlights interviewee resistance. The politician counterchallenges in turn 2 by reflecting back the question to the interviewer, an equivocation technique according to Bull (2003).

The journalist in turn 3 strikes back, by reflecting the question back to the politician 'you have not asked them?' adding another adversarial question 'how are you going to do this?' that invites the politician to account for his future actions. In turn 4 the politician responds by implying that he has already answered the questions 'but I am saying, that I am telling you, and I am answering that', using the disjunctive ' $\mu \alpha$-but' and stressing the relevant verbs, not repeating his answer though. This is an equivocation technique according to Bull (2003), or a covert resistance technique according to Clayman and Heritage (2002). 
In turn 5, the journalist latches and provides the expected answer to the question himself 'they accept them (you are telling me)'. By co-constructing the politician's answer the journalist breaches neutralism, takes up the role of the 'author' and the 'principal', in Goffman's (1981) terms, of the proposition expressed in the answer to the accountability question and aids the politician in the development of his argument.

In turn 6 the politician repeats the journalist's words 'they (...) accept them' adding and stressing ' $\pi \rho \varepsilon \dot{\varepsilon} \pi \varepsilon l$ - have to', which seems to be an effort to have some kind of control over what is being said. The politician in his turn though, does not change the propositional content of the answer offered by the journalist in the previous turn. By repeating almost verbatim the journalists' words, the politician validates both the interactional move and its content.

What is equally interesting in this extract is that collaborative completion comes after a series of 'adversarial challenges' and 'evasive responses' with both interlocutors shifting between accountability interview and ordinary conversation frames within 10 seconds. The exchange finishes off with the journalist using ' $\mu \alpha \dot{\lambda} \lambda \sigma \tau \alpha$-right' in turn 7, a discourse marker indicating acknowledgement and acceptance of the previous answer.

Following Norrick (2010), I would argue that, in this case, the collaborative completion, in the form of the journalist answering his own question after the politician evaded answering it by indicating that he has already done so, addresses both the interviewee and the overhearing audience. In this case though, as the context is different from the one in Norrick's study and the purpose of the election campaign interview is different from that of the celebrity interview, the function of the collaborative completion is different. In Norrick's dataset it was to entertain and make the interview more vivid, while in this case it is to help the politician answer a difficult question, thus maintaining the face he lost by not answering and to keep the interview going. 
Extract 2 This extract is taken from the first two minutes of a quite long (42'30") face to face interview between Alexis Tsipras, leader of Syriza (a left-wing party) and the host of an early morning weekend news and current affairs programme that was broadcast every weekend on a private TV channel (SKAI). The journalist (George Autias) is a well-known presenter of that type of TV programmes. The interview was broadcast on 20/5/2012 after the first round of elections. At the beginning of the interview the journalist had asked the politician what the first three measures of his government would be if he won the elections (a policy promising question according to Clayman and Romaniuk, 2011). The politician started answering by detailing the measures his government would take to help the most vulnerable by utilizing unused financial resources. The journalist, eight turns before the excerpt, asked the politician another promise soliciting question, whether this money would come from the National Strategic Reference Framework ${ }^{2}$ (NSRF), a commitment/clarification the politician did not make in his subsequent turns.

Video: 02:06-02:12

Audio: 40:24-40:18

\begin{tabular}{|c|c|c|c|c|}
\hline 1 & $\Delta \eta \mu .:$ & $=\mu \varepsilon \uparrow \tau \iota \lambda \varepsilon \downarrow \varphi \tau \alpha \dot{\alpha} \kappa . \pi \rho \delta^{\prime} \varepsilon \delta \rho \varepsilon ?=$ & Jour.: & $\begin{array}{l}=\uparrow \text { where would the } \downarrow \text { money come } \\
\text { from Mr President? }\end{array}$ \\
\hline 2 & Под. & $={ }^{\circ} \mu \alpha \sigma \alpha \varsigma \varepsilon 1 \pi-\sigma \alpha \varsigma \lambda \varepsilon^{\prime} \omega^{\circ},=$ & Pol. & $=\circ$ but I tol-I am telling you, ${ }^{\circ}=$ \\
\hline 3 & $\Delta \eta \mu .:$ & 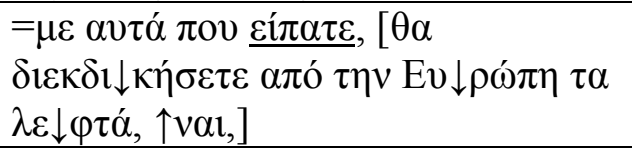 & Jour.: & $\begin{array}{l}=\text { from where you said, }[\text { the } \\
\downarrow \text { money you will } \downarrow \text { claim from } \\
\downarrow \text { Europe, } \uparrow \text { yes, }]\end{array}$ \\
\hline 4 & Под.: & 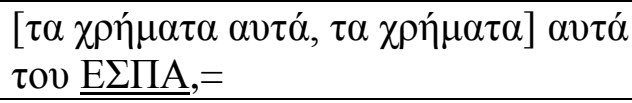 & Pol.: & $\begin{array}{l}\text { [that money, the money] from the } \\
\text { NSRF, }=\end{array}$ \\
\hline 5 & $\Delta \eta \mu .:$ & $=\uparrow v \alpha l,=$ & Jour.: & $=\uparrow$ yes, $=$ \\
\hline
\end{tabular}

In turn 1, the journalist latches and asks a pursuit (Romaniuk, 2013), 'where would the money come from Mr President?' a slightly modified version of the question he had asked eight turns before. Although the initial question, not included, 'عvvocí $\varepsilon \varepsilon$ E $\Sigma \Pi A-$ you mean 


\section{Kantara}

NSRF' was a narrow yes/no question, the repetition is a rather broad 'wh'-question, allowing the politician greater space to maneuver.

The politician though seems once again reluctant to commit himself to a specific answer and responds by using the same evasion/covert resistance technique as the politician in extract 1. In particular he indicates that he has already answered the question, in lower voice though in contrast to the politician in extract 1 , using the disjunctive ' $\mu \alpha$-but' and the relevant verbs ' $\sigma \alpha \varsigma \varepsilon \imath \pi-\sigma \alpha \varsigma \lambda \varepsilon^{\varepsilon} \omega$ - I to-I am telling you' but not repeating his answer.

In a similar fashion as the journalist in the previous extract, the journalist in turn 3 latches and provides the answer to the question himself 'the money you will claim from Europe' and a reactive token ' $v \alpha l$-yes' indicating listener recipiency acknowledgement. What differentiates though this journalist's collaborative completion from the one exhibited by the journalist in the previous example is the use of the phrase ' $\mu \varepsilon \alpha v \tau \alpha$ ' $\pi o v \varepsilon i \pi \alpha \tau \varepsilon$-from where you said' before providing the answer, the use of which (and the stress of the verb 'cí $\alpha \tau \varepsilon$ said' explicitly indicates that the politician has already answered the question. By doing so, the journalist renders his own challenging question/pursuit as not legitimate and legitimises the politician's non-answer. In this way, he both saves the politician's face and keeps the interview going by having 'elicited' news.

The politician in turn 4, after the overlapping talk, answers the question asked 'that money, the money from NSRF' by using and stressing the cue given by the journalist in the

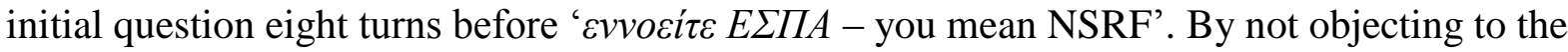
propositional content of the journalist's answer 'the money you will claim from Europe' and by using the cue provided before, the politician validates both the collaborative 'completion' of his turn/argument and the content of the interactional move. 
In the next four extracts, three different journalists help four different political party leaders coming from different political parties to construct their arguments. They do so by proposing a word or a phrase on different points during the interview. These range from providing the word or phrase the politician was looking for after the latter paused to latching and providing themselves a word or phrase.

Extract 3 - The extract is taken from a short interview (13') via link between the then general secretary of the Communist Party of Greece (KKE) Aleka Papariga, and a leading journalist (Maria Houkli) of a private TV channel (ANT1). The interview was broadcast after the first round of elections during the 8 o'clock evening news on June $11^{\text {th }} 2012$.

Video: 08:24-08:35

Audio: 04:34-04:25

\begin{tabular}{|c|c|c|c|c|}
\hline 1 & Под.: & 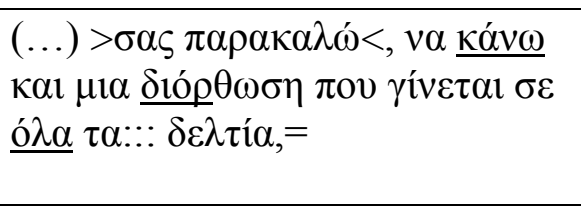 & Pol.: & $\begin{array}{l}(\ldots)>\text { please }<, \text { may I make a } \\
\text { correction, something that is } \\
\text { happening in a::::ll news } \\
\text { bulletins, }=\end{array}$ \\
\hline 2 & $\Delta \eta \mu .:$ & $=\mu \mu,=$ & Jour: & $=\mathrm{mm},=$ \\
\hline 3 & Под.: & 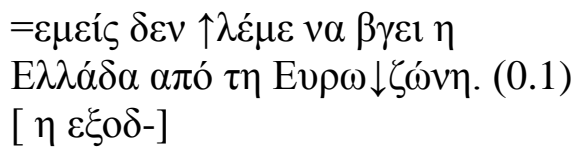 & Pol: & $\begin{array}{l}=\text { we do not } \uparrow \text { say Greece to exit } \\
\text { the } \downarrow \text { eurozone. }(0.1) \text { [exi-] }\end{array}$ \\
\hline 4 & $\Delta \eta \mu:$ & 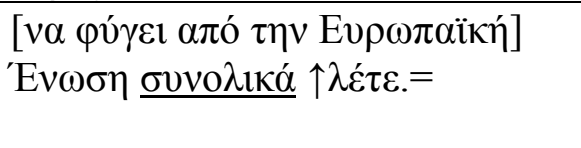 & Jour: & $\begin{array}{l}\text { [to withdraw from the } \\
\text { European] Union you are } \\
\uparrow \text { saying.= }\end{array}$ \\
\hline 5 & Под.: & 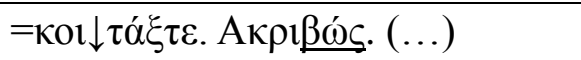 & Pol: & $=\downarrow$ look. Exactly. (...) \\
\hline
\end{tabular}

In turn 1 the politician asks for the journalist's permission to clarify a general policy issue point she feels is being misrepresented in all news bulletins. After being granted permission by the journalist, the politician in turn 3 explains where her party stands on the relations with the EU. In turn 4, the journalist overlaps and completes the politician's sentence 'to withdraw from the European Union'.

In the context of ordinary conversation the journalist's interactional move of overlapping would be quite legitimate, as it came after a one second pause on the part of the politician, i.e. in a Transition Relevance Place (TRP) for Sacks, Schegloff and Jefferson (1978). In the 


\section{Kantara}

context of the 'hard' one-on-one election campaign interviews though, as already discussed, it is 'unacceptable', as journalists should not indicate active listenership ${ }^{3}$.

What is more, the journalist, by overlapping and finishing off the politician's turn, occupies the role of the author of the proposition expressed, while her role is 'just' that of the animator (in Goffman's 1981 terms). By co-constructing the politician's talk the journalist not only breaches neutralism but also aids the politician in the development of her argumentation. In this case also, the reactive token addresses both the politician and the audience as the journalist's turn both helps the politician and informs the public of her party's manifesto.

The politician in turn 5, by using and stressing ' $A \kappa \rho \imath \beta \omega$-exactly', confirms the journalist's continuation as valid in terms of informational content. By doing so she indicates that she does not object either to the breach of neutralism or the content of the overlapping speech, legitimising thus the journalist's interactional move/listener activity as appropriate for the speech event. In the next extract a similar active listener activity is used by another journalist.

Extract 4 - This extract is taken from a quite long interview (27' 28") via link between the leader of Independent Greeks (a right-wing, anti-austerity, nationalist party) Panos Kammenos, and George Autias, the host of an early morning weekend news and current affairs programme broadcast every weekend in a private TV channel (SKAI). The interview was broadcast after the first round of elections on June $10^{\text {th }} 2012$.

Video: 10:51-11:13

Audio: 17:36-17:13

\begin{tabular}{|c|c|c|c|c|}
\hline 1 & Под.: & 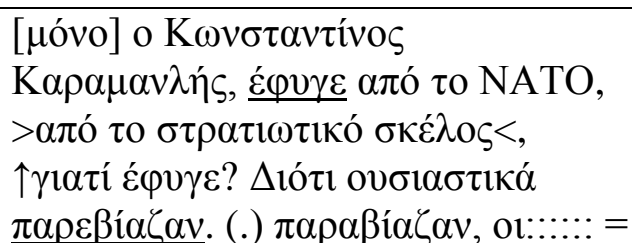 & Pol.: & $\begin{array}{l}\text { [only] Constantinos Karamanlis, } \\
\text { left NATO, >from the military } \\
\text { part }<, \uparrow \text { why did he leave? Because } \\
\text { they basically breached. (.) } \\
\text { breached the:::::= }\end{array}$ \\
\hline 2 & $\Delta \eta \mu .:$ & 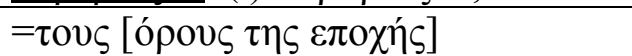 & Jour.: & $=$ the [terms of the period] \\
\hline 3 & По $\lambda$ : & 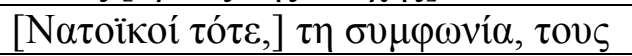 & Pol.: & [NATO officials then,] the \\
\hline
\end{tabular}




\begin{tabular}{|c|c|c|c|c|}
\hline & & ó $\rho \circ v_{\zeta} \kappa \alpha 1, \pi-\varepsilon^{\prime} \chi \alpha \mu \varepsilon \tau \eta \nu \varepsilon,=$ & & $\begin{array}{l}\text { agreement, the terms and } \mathrm{p} \text { - we } \\
\text { had the, e,= }\end{array}$ \\
\hline 4 & $\Delta \eta \mu .:$ & 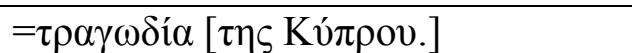 & Jour:: & $=$ tragedy [in Cyprus.] \\
\hline 5 & Под.: & 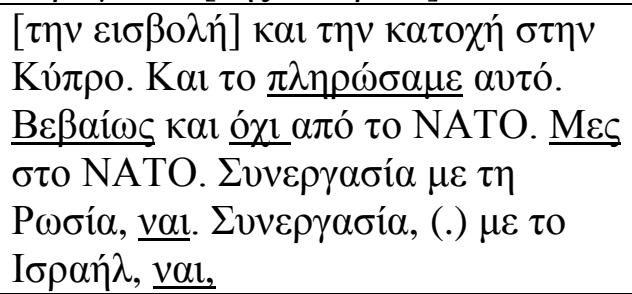 & Pol: & $\begin{array}{l}\text { [the invasion] and occupation in } \\
\text { Cyprus. And we paid dearly for } \\
\text { this. Of course not to leave NATO. } \\
\text { Inside NATO. Cooperation with } \\
\text { Russia, yes. Cooperation, (.) with } \\
\text { Israel, yes, }\end{array}$ \\
\hline
\end{tabular}

In turns 2 and 4, the journalist latches and provides the phrases the politician is looking for. As was the case in the previous extract, the journalist's help/interactional move is 'legitimate' in the context of ordinary conversation (as in both cases it came at a TRP), but not in institutional interaction. In particular, in turn 2 the journalist latches and helps the politician who is evidently trying to find the right phrase in the previous turn. This is indicated by the politician's hesitations, marked by his falling tone after the verb ' $\pi \alpha \rho \varepsilon \beta i \alpha \zeta \alpha \nu$-breached', followed by a one minute pause, indicated in the transcript by the use of a full stop and a full stop within brackets respectively. Furthermore, the politician repeats the same verb ' $\pi \alpha \rho \varepsilon \beta i \alpha \zeta \alpha \nu$-breached' and stretches the article 'ol-the' both signs of him hesitating, not sure how to proceed.

In turn 4 once again the journalist latches and provides the phrase ' $\tau \rho \alpha \gamma \omega \delta i \alpha \tau \eta \varsigma$ Kvi $\pi \rho o v$ - tragedy in Cyprus' the politician was looking for in the previous turn. In this case, the politician's hesitation in turn 3 is evident by his sharply cutting his talk in progress, indicated in the transcript by a dash, probably changing his mind about his choice of words, and also the use of the hesitation marker ' $\varepsilon$-e' at the end of the turn. All these features in the politician's speech indicate that he is looking for the right phrase, which is provided by the journalist. In this case I would argue that the journalist's latching verges between help and interpretation. Norrick (2010: 535) points out that 'interviewers do not just suggest words (...) to their interviewers, they sometimes proffer formulations of what their interviewees are getting at.' This seems to be the case here as the word ' $\tau \rho \alpha \gamma \omega \delta i \alpha$-tragedy', suggested by the 


\section{Kantara}

journalist to describe what happened in Cyprus in July 1974, is a word with very strong connotations, a word one would assume the leader of a nationalist party would use to describe what had happened.

As in all the examples discussed so far, the politician in turns 3 and 5 uses the word/phrase provided by the journalist as a cue in his own turn, either verbatim and stressing them ('ó $\rho o v \varsigma$-terms' in turn 3) or by slightly changing/modifying them (the general umbrella word, in this context, ' $\tau \rho \alpha \gamma \omega \delta i \alpha^{\alpha}$ - tragedy' provided by the journalist in turn 4 is changed to the more specific words ' $\varepsilon l \sigma \beta o \lambda \eta ́$-invasion' and ' $\kappa \alpha \tau o \chi \eta ́$-occupation' in turn 5).

In this case also, the reactive tokens used, address both the politician and the audience as the journalist's turns help the politician develop his argument and at the same time keep the interview going. The next extract taken from the same interview as Extract 1 exhibits a listener activity once again on the verge between the journalist helping the politician and interpreting what he is getting at.

Extract 5 - The politician is Antonis Samaras, the then leader of New Democracy (a conservative, liberal party) and the interviewer is Yiannis Pretenteris.

Video: 08:41-09:24

Audio: $31: 30-30: 48$

\begin{tabular}{|c|c|c|c|c|}
\hline 1. & $\Delta \eta \mu .:$ & 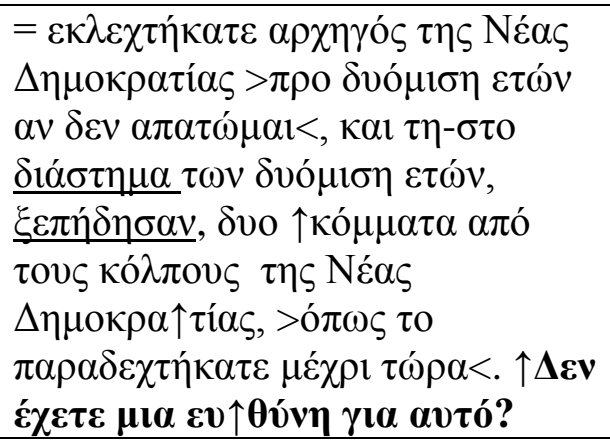 & Jour.: & $\begin{array}{l}=\text { you were elected New } \\
\text { Democracy president }>\text { two and a } \\
\text { half years ago, if I am not } \\
\text { mistaken<, and in-in this period, } \\
\text { two political } \uparrow \text { parties were formed } \\
\text { from within New De } \uparrow \text { mocracy, } \\
>\text { as you yourself have admitted }<\text {. } \\
\uparrow \text { Don’t you have any } \\
\text { respon } \uparrow \text { sibility for this? }\end{array}$ \\
\hline 2. & Под.: & 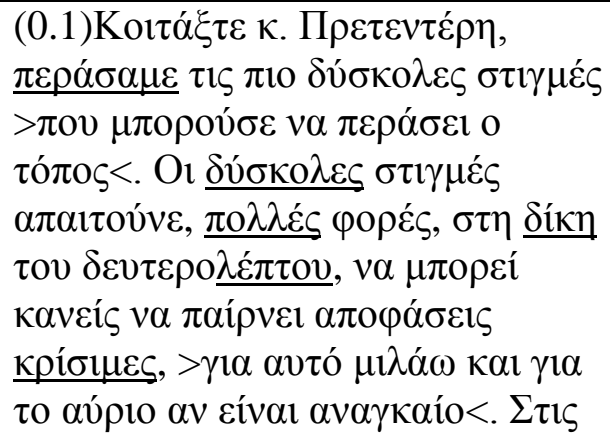 & Pol.: & $\begin{array}{l}\text { (0.1)Look Mr Pretenteris, we } \\
\text { went through the most difficult } \\
\text { times }>\text { we could ever go } \\
\text { through }<\text {. In difficult times like } \\
\text { these, one has to really quickly } \\
\text { make crucial decisions, }>\text { that is } \\
\text { why I'm also talking about the } \\
\text { future if need arises }<\text {. } \uparrow \text { Some can } \\
\text { deal with the crucial decisions }\end{array}$ \\
\hline
\end{tabular}




\begin{tabular}{|c|c|c|c|c|}
\hline & & 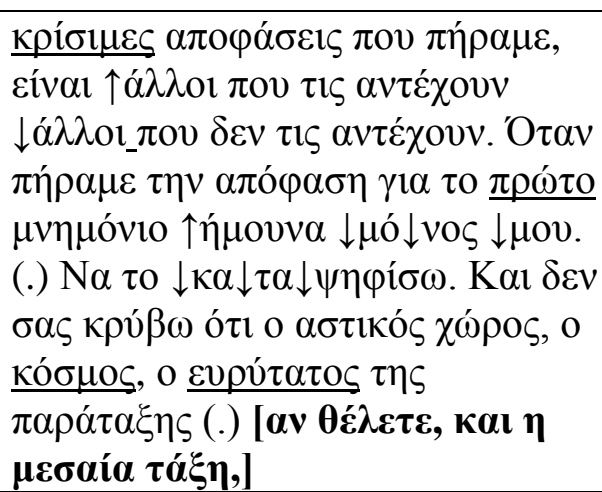 & & $\begin{array}{l}\text { taken, } \downarrow \text { some cannot. When we } \\
\text { decided to vote against the first } \\
\text { memorandum } \downarrow I \downarrow \text { was } \downarrow \text { alone. (.) } \\
\text { in my decision to } \downarrow \text { vote } \downarrow \text { against } \\
\text { it. And it's a common secret that } \\
\text { the bourgeois, the major pool of } \\
\text { our voters (.) [and even middle } \\
\text { class people,] }\end{array}$ \\
\hline 3. & $\Delta \eta \mu .:$ & 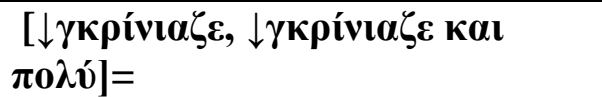 & Jour.: & $\begin{array}{l}\text { [were } \downarrow \text { nagging, were } \downarrow \text { nagging } \\
\text { a lot] }=\end{array}$ \\
\hline 4. & Под.: & 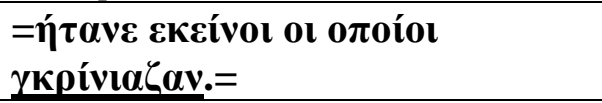 & Pol.: & $=$ were the ones nagging.= \\
\hline 5. & $\Delta \eta \mu .:$ & $=v \alpha \mathrm{l}, v \alpha \mathrm{l}=$ & Jour.: & $=$ yes, yes= \\
\hline
\end{tabular}

The extract starts with the journalist in turn 1 asking an accountability question (in bold) involving a proposition that portrays the politician in a negative light by means of using a negative interrogative (Greatbatch, 1998; Clayman and Heritage, 2002; Heritage and Clayman, 2010; Heritage, 2002). The negative interrogative 'Don't you have any responsibility for this?' presupposes that the politician has some responsibility for the formation of two parties from within New Democracy after he expelled their members for either voting in favour of the first Memorandum or against the second. It invites the politician to either agree or disagree with the fact that he has some responsibility for this, a challenging situation, as he has to defend his decisions without taking on any responsibility that would portray him as making mistakes and/or being inconsistent.

The politician's response in turn 2, reflects this tricky interactional task of him trying to shift the topic from his responsibility for the formation of two other parties from within his own party to his responsibility as a leader in times of crisis. This involves him making a semantic shift in the meaning of the word ' $\varepsilon v \theta v v \eta$-responsibility', a covert resistance technique according to Clayman and Heritage (2002). And it is while the politician builds his argument in relation to what he did during the very difficult period the country was going through, discussing his supporters' reactions, after a micropause on his part, that the 


\section{Kantara}

journalist overlaps, in which he offers a formulation ' $\gamma \kappa \rho i v l \alpha \zeta \varepsilon, \gamma \kappa \rho i v l \alpha \zeta \varepsilon \kappa \alpha l \pi o \lambda v^{\prime}$ - were nagging, were nagging a lot' that supposedly reflected the situation back then (both are indicated in bold).

This case is different from the ones discussed so far, as the politician was not evidently looking for a word or a phrase, so the journalist's overlap did not come at a TRP. It is important to note here, that, although the journalist's overlap came after a micropause, this was very brief, less than one-tenth of a second, thus not a legitimate TRP. For this reason I argue that, in this case, what the journalist is doing is to co-narrate the politician's answer with him. In ordinary conversation terms, it would be as if they co-narrated a story, an interview activity frequently found in (tabloid) talk shows (Thornborrow, 2001). In that sense, this is really a joint production of the politician's argument, a listener activity addressed both to the politician and the audience. What is equally important to note here is that, in a similar way as in Extracts 1 and 2, the journalist's co-operative overlap during the politician's response seems to cancel his own challenging move in the first turn.

The politician's reaction in the next turn, in bold, where he takes up the phrase offered

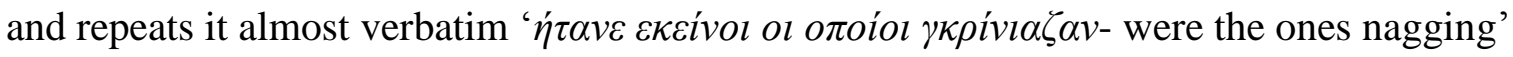
stressing also the verb, indicates acceptance of both the content and the interactional move made by the journalist. The next extract taken from the same interview as Extract 2 exhibits a listener activity that is on the verge of the journalist guessing what the politician is getting at and imposing his interpretation of what he is getting at.

Extract 6 - The politician is Alexis Tsipras, leader of Syriza (a left-wing party) and the journalist is George Autias.

Video: 30:34-30:46

Audio: 12:08-11:46

\begin{tabular}{|c|c|c|c|c|}
\hline 1 & Под: & 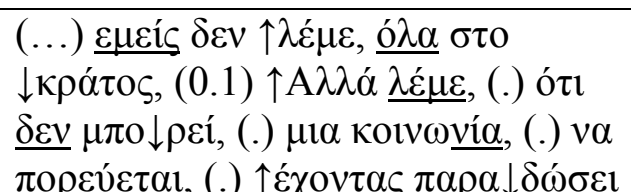 & Pol: & $\begin{array}{l}(\ldots) \text { we are not } \uparrow \text { saying, everything } \\
\text { should be } \downarrow \text { state owned. } \uparrow \text { But we are } \\
\text { saying, that a society } \downarrow \text { cannot, move } \\
\text { on. } \uparrow \text { having } \downarrow \text { given everything in to }\end{array}$ \\
\hline
\end{tabular}




\begin{tabular}{|c|c|c|c|c|}
\hline & & 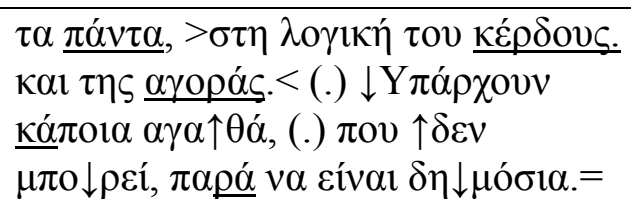 & & $\begin{array}{l}\text { the logic of the market and the } \\
\text { profit. There } \downarrow \text { are certain goods, (.) } \\
\text { that } \uparrow \text { cannot } \downarrow \text { be anything else but } \\
\text { public. }=\end{array}$ \\
\hline 2 & $\Delta \eta \mu:$ & $=\eta \downarrow v \gamma \varepsilon i ́ \alpha,=$ & Jour: & $=\downarrow$ health,$=$ \\
\hline 3 & По $\lambda$ : & $=\eta \downarrow v \gamma \varepsilon i ́ \alpha,=$ & Pol: & $=\downarrow$ health, $=$ \\
\hline 4 & $\Delta \eta \mu:$ & $=\eta \alpha \sigma \varphi \downarrow \alpha \dot{\lambda} \varepsilon 1 \alpha,=$ & Jour: & $=$ se $\downarrow$ curity, $=$ \\
\hline 5 & Пол: & $=\eta \pi \alpha \imath \uparrow \delta \varepsilon i ́ \alpha,=$ & Pol: & $=\underline{\mathrm{edu}} \uparrow \underline{\text { cation }},=$ \\
\hline 6 & $\Delta \eta \mu:$ & 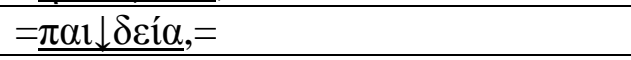 & Jour: & $=\underline{\text { edu }} \downarrow$ cation, $=$ \\
\hline 7 & Пол: & 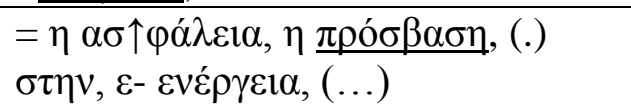 & Pol: & $\begin{array}{l}=\text { se } \uparrow \text { curity, having access, to, e- } \\
\text { energy, (...) }\end{array}$ \\
\hline
\end{tabular}

From turn 2 to turn 7 we have a very interesting series of collaborative completions of the politician's political manifesto that started in turn 1 .

In turns 2 and 4, the journalist latches and starts listing the goods that should be public, taking over the role of the politician as the interviewee. In this case the journalist is not only the 'author' but arguably also the 'principal' of the words uttered, as by providing the answer he seems also to endorse the proposition expressed. In contrast to all the other extracts examined so far, the journalist's latching is not legitimatized in any way, as the politician did not hesitate in any way immediately prior to the overlap ${ }^{4}$, so the journalist did not latch in a TRP.

The politician, by repeating the word 'vyci $\alpha$-health' in turn 3, agrees with the view expressed by the journalist in the previous turn that 'health' is the most important public good, accepting the journalist's role as the author and principal of the proposition. By using a reactive token (repetition) himself, the politician indicates his compliance with coconstructing the narrative of his manifesto.

In turn 5 though, he seems to disagree with the journalist's 'suggestion' in the previous turn, as he does not repeat ' $\alpha \sigma \varphi \alpha ́ \lambda \varepsilon \imath \alpha$-security' as the second most important good that should be public, but says ' $\pi \alpha l \delta \varepsilon i \alpha$-education'. What is important though is that this is done within the co-constructing turns pattern adopted by both parties, with no marked disruption. In turn 5 the politician claimed back the role of the 'author' and 'principal' of the 


\section{Kantara}

utterance, but he did so in an interactionally cooperative way. In other words, he did not interactionally challenge the journalist but he reclaimed his role as the interviewee by latching, without though using a reactive token (repetition) as he did in the previous turn. By doing so, he indicates that he disagreed with the content of the previous turn but not with the interactional pattern of co-constructing turns.

In turn 6, the journalist repeats the politician's word 'education' uttered in the previous turn, an interactional move that maintains the pattern of co-constructing turns, but at the same time acknowledges that the politician is the 'author' and 'principal' of the views expressed and that the journalist is 'just' acknowledging the previous turn, granting thus the interviewee role as the one providing answers to questions, back to the politician.

What is also interesting is that in turn 7 the politician reintroduces ' $\alpha \sigma \varphi \alpha ́ \lambda \varepsilon \imath \alpha-$ security' that was introduced by the journalist in turn 4 as a good that should be public but he modifies it by making a semantic shift in its meaning that enables him to introduce a slightly different topic. Instead of talking about 'security from outside and inside enemies of the country' the politician talks about people feeling secure that they have access to essential goods like electricity, and how this would be jeopardized if the Public Electricity Company were privatized as intended (this part of the extract is not included). So even if he changes the semantic meaning of 'security' to suit his purposes, the politician, by doing so, acknowledges the journalist's contribution to the unfolding interaction and uses it to develop his own argument.

Whether the journalist's collaborative completions addressed the politician or the audience or both is ambiguous, since as discussed above the politician did not hesitate prior to the overlap so he was not 'in need' of help. Based on that I would argue that the overlap was manipulative (in Norrick's 2010 terms), trying to impose the journalist's views on which goods should be public, to both the politician and the audience. 


\section{Discussion/Conclusion}

In this paper I examined the hybrid listening practices of Greek journalists in the 'hard' political news interview genre of election campaign interviews. Previous research findings in relation to the function of hybrid listening practices in the context of Swedish political radio talk shows (Ekström, 2011, although he did not explicitly use the term listening practices) indicated that journalists can use evaluative responses and response tokens in third position, mainly to challenge the politician. In particular, the journalist in Ekström's study, used these reactions to question what the interviewee was doing, to play with the interviewee's identity and to highlight distinctions between the lay and the expert.

In my data however, journalists use reactive tokens in third position to collaboratively complete politicians' arguments and to answer their own questions. In other words, journalists in my dataset use reactive tokens in third position not to challenge but to 'help' the politicians by co-constructing their turns/arguments. The use of reactive tokens within the same interactional sequence results in two distinct and, arguably, contradictory speech exchange systems to be merged and invoked: adversarial or challenging questioning, typical of the political news interview genre on the one hand and listener activities typical of everyday conversation on the other. By doing so, journalists in my dataset breach the taken for granted professional value of neutralism ${ }^{5}$, and transform the 'hard' genre of election campaign interviews into a hybrid form where 'serious' accountability practices are merged with (celebrity and even tabloid) talk show practices (see also Hutchby, this issue). This seems to be in line with both Ekström's (2011: 151) claim about the utilization of a talk show format in the high profile election campaign interview area and Patrona's (2011) claim that the norm of journalistic neutralism in news interviews needs to be re-examined taking into account different socio-cultural contexts. 
What significantly differentiates the way journalists in my dataset utilize hybrid interactional practices in the election campaign interview genre from the way this was done in previous research, is its local function. Although in Ekström's case study the journalist used hybrid listening practices to challenge the politician, journalists in my case used hybrid listening practices to 'help' the politician develop his/her argument. By facilitating the development of the politicians' arguments and/or co-narrating their 'stories'/manifestos, journalists co-construct knowledge for the overhearing audience, and aid politicians' practical process of persuasion (or propaganda in Taylor's 1992 terms).

Politicians on the other hand, by accepting ${ }^{6}$, or reacting to the content of the turn, but not the breach of neutralism, indicate both that this transformed form of neutralism is coconstructed and that it serves their practical process of persuasion.

So it seems that this co-transformed, hybrid from of neutralism, produces coconstructed social knowledge for the overhearing audience, facilitating each and every time the politician's propaganda, regardless of the political spectrum s/he is in. This partly supports Patrona's (2011: 174) claim that (Greek) journalistic standards for news interviewing favour 'the construction of societal consensus by 'imposing' preferred readings of public politics on the audience.' Journalists in my dataset did indeed do that, through their listening practices that addressed politicians from different political parties. As all politicians accepted the interactional move, I would argue that the societal consensus was collaboratively constructed and imposed on the audience. In other words, journalists' hybrid listening practices provided political actors with new ways to mainstream their manifestos and subsequently appropriate them to the public domain. Or to use Warner's (2002) notion of 'counterpublic discourse,' as discussed by Martin (2013: 143-144), it could also be argued that the hybrid listening practices journalists employed in my dataset, function as 
'counterpublic discourses', in the sense that they help transform the public domain by providing new means to talk about situations (political manifestos in this case) and guiding the audience in how to respond to them.

\section{Appendix (Transcription Glossary)}

(adapted from Hutchby and Wooffitt (1999))

\begin{tabular}{|c|c|}
\hline$\uparrow \downarrow$ & $\begin{array}{l}\text { pointed arrows indicate a marked falling or rising intonation in non-final } \\
\text { position }\end{array}$ \\
\hline$><$ & $\begin{array}{l}\text { 'more than' and 'less than' signs indicate that the talk they encompass was } \\
\text { produced noticeably quicker than the surrounding talk. }\end{array}$ \\
\hline$\langle>$ & $\begin{array}{l}\text { used in the reverse order they indicate the encompassed talk is markedly } \\
\text { slower or drawn out. }\end{array}$ \\
\hline$\circ \circ$ & degree marks indicate decreased volume of talk between \\
\hline$\underline{\text { Under }}$ & underlined fragments indicate speaker emphasis \\
\hline CAPITALS & $\begin{array}{l}\text { words in capitals mark a section of speech noticeably louder than that } \\
\text { surrounding it. }\end{array}$ \\
\hline (guess) & $\begin{array}{l}\text { the words within a single bracket indicate the transcriber's best guess at an } \\
\text { unclear utterance. }\end{array}$ \\
\hline ( ) & empty parentheses indicate the presence of an unclear fragment on the tape. \\
\hline$\cdot$ & $\begin{array}{l}\text { a full stop indicates a stopping fall in tone. It does not necessarily indicate the } \\
\text { end of a sentence. }\end{array}$ \\
\hline , & a comma indicates a 'continuing' intonation. \\
\hline$(0.5)$ & the number in brackets indicates a time gap in tenths of a second. \\
\hline (.) & $\begin{array}{l}\text { a dot enclosed in a bracket indicates a pause in the talk of less than one-tenth of } \\
\text { a second. }\end{array}$ \\
\hline$=$ & $\begin{array}{l}\text { the 'equals' sign indicates 'latching' between utterances, produced either by the } \\
\text { same speaker, to accommodate for overlapping speech, or different speakers }\end{array}$ \\
\hline [ ] & $\begin{array}{l}\text { square brackets between adjacent lines of concurrent speech indicate the onset } \\
\text { and end of a spate of overlapping talk. }\end{array}$ \\
\hline$?$ & question mark indicates upward intonation in final position \\
\hline- & a dash indicates the sharp cut-off of the prior word or sound \\
\hline
\end{tabular}


\begin{tabular}{l|l}
$:$ & colons indicate that the speaker has stretched the preceding sound or letter. The
\end{tabular} more colons the greater the extent of stretching.

\section{Acknowledgements}

I would like to thank the anonymous reviewers for their constructive feedback on an earlier draft of this paper. Needless to say that any shortcomings are entirely my own.

\section{Notes}

1 Neutralism as discussed by Clayman (1992) and Greatbatch (1998), cited in Hutchby (2006:127), refers to the fact that journalists actually achieve the status of 'being neutral', through a set of specialised discourse practices.

2 The NSRF (National Strategic Reference Framework) constitutes the reference document for the programming of European Union Funds at national level for a given period (source: http://www.espa.gr/EN/Pages/staticWhatIsESPA.aspx)

3 But see Patrona (2006, 2009, 2011) for a discussion of the interviewing practices of Greek journalists during prime-time TV news debates and political talk shows.

4 The full stop used in the transcript after the last word uttered by the politician before the journalist latched, indicates a stopping fall in tone. It does not necessarily indicate the end of a sentence.

5 See also Tolson (2012) for a discussion on the non-compliance of journalists to neutralism in his longitudinal (1983-2000) study of UK election interviews and Patrona (2011) for a discussion on how neutralism is practiced by journalists in Greek evening news.

6 See also Bull and Fetzer (2006) for politicians accepting presuppositions of journalists.

\section{References}

Bull PE (2003) The Microanalysis of Political Communication. London: Routledge.

Bull P and Fetzer A (2006) Who are we and who are you? The strategic use of forms of address in political interviews. Text \& Talk 26(1): 3-37. 
Clancy PM, Thomson SA, Suzuki R and Tao H, (1996) The conversational use of reactive tokens in English, Japanese and Mandarin. Journal of Pragmatics 26: 355-387.

Clayman SE (1992) Footing in the achievement of neutrality: The case of news interview discourse. In: Drew P and Heritage J (eds) Talk at Work. Cambridge: Cambridge University Press, pp. 163-198.

Clayman SE and Heritage J (2002) The News Interview: Journalists and Public Figures on the Air. Cambridge: Cambridge University Press.

Clayman SE (2007) Speaking on behalf of the public in broadcast news interviews. In: Holt E and Clift R (eds) Reporting Talk: Reported Speech in Interaction. Cambridge: Cambridge University Press, pp.221-243.

Clayman SE and Romaniuk T (2011) Questioning candidates. In: Ekstrom M and Patrona M (eds) Talking Politics in Broadcast Media: Cross Cultural Perspectives on Political Interviewing, Journalism and Accountability. Amsterdam: John Benjamins, pp.15-32.

Ekström M and Kroon Lundell A (2009) The news interview: Diversity and hybridity in the communicative activities of broadcast news. In: Proceedings of the 19th Nordic Conference for Media and Communication Research, Sweden, Karlstad 13-15 August 2009. Available at: http://nordicom.statsbiblioteket.dk/ncom/en/publications/thenews-interview(39c4a890-3738-11df-bf62-000ea68e967b)/export.html (accessed: 27 October 2015).

Ekström M (2011) Hybridity as a resource and challenge in a talk show political interview. In: Ekström M and Patrona M (eds) Talking Politics in Broadcast Media: Cross Cultural Perspectives on Political Interviewing, Journalism and Accountability. Amsterdam: John Benjamins, pp.135-155.

Gardner R (1997) The conversational object mhm: Weak and variable acknowledging token. Research on Language and Social Interaction 30(2): 31-135. 


\section{Kantara}

Gardner R (1998) Between speaking and listening: The vocalisation of understandings. Applied Linguistics 19(2): 204-24.

Gardner R (2001) When Listeners Talk: Response Tokens and Listener Stance. Amsterdam: John Benjamins.

Goffman E (1974) Frame Analysis. Cambridge, MA: Harvard University Press.

Goffman E (1981) Footing. In: Goffman E (ed) Forms of Talk. Oxford: Blackwell, pp.124159.

Goodwin C (1986) Between and within: alternative sequential treatments of continuers and assessments. Human Studies 9: 205-217.

Greatbatch D (1998) Conversation analysis: Neutralism in British news interviews. In: Bell A and Garrett P (eds) Approaches to Media Discourse. Oxford: Blackwell, pp.163-185.

Heritage J (1984) A change-of-state token and aspects of its sequential placement. In:

Atkinson JM and Heritage J (eds) Structures of Social Action. Cambridge: Cambridge University Press, pp. 299-345.

Heritage $\mathbf{J}$ (1985) Analysing news interviews: Aspects of the production of talk for an overhearing audience. In: Van Dijk T (ed) Handbook of Discourse Analysis, Volume 3: discourse and Dialogue. London: Academic Press, pp. 95-117.

Heritage J (2002) The limits of questioning: negative interrogatives and hostile content. Journal of Pragmatics (34): 1427-1446.

Heritage J and Clayman SE (2010) Talk in Action: Interactions, Identities and Institutions.

Chichester: Wiley-Blackwell

Hutchby I (2006) Media Talk: Conversation Analysis and the study of Broadcasting. Berkshire: Open University.

Hutchby I (2011a) Doing non-neutral: Belligerent interaction in the hybrid political interview. In: Ekstrom M and Patrona M (eds) Talking Politics in Broadcast Media: 
Cross Cultural Perspectives on Political Interviewing, Journalism and Accountability. Amsterdam: John Benjamins pp.115-133.

Hutchby I (2011b) Non-neutrality and argument in the hybrid political interview. Discourse Studies 13(3): 349-365.

Hutchby I (2016) Hybridisation, personalisation and tribuneship in the political interview.

\section{Journalism xxx}

Levinson SC (1992) Activity types and language. In: Drew P and Heritage J (eds) Talk at Work. Cambridge: Cambridge University Press, pp. 66-100.

Linell P (2011) Samtalskulturer. Kommunikativa Verksamhetstyper i Samhället

[Conversational Cultures. Communicative Activity Types in Society] (Vols. 1 and 2). Linköping, Sweden: Linköping University.

Martin J (2013) Politics \& Rhetoric. London: Routledge.

McCarthy M (2003) Talking back: 'small' interactional response tokens in everyday conversation. Research on Language and Social Interaction 36(1): 33-63.

Maynard SK (1990) Conversation management in contrast: Listener responses in Japanese and American English. Journal of Pragmatics 14: 397-412.

Montgomery M (2007) The Discourse of Broadcast News: A Linguistic Approach. London: Routledge.

Norrick NR (2010) Listening practices in television celebrity interviews. Journal of Pragmatics 42(2): 525-543.

Patrona M (2006) Conversationalisation and media empowerment in Greek television discussion programmes. Discourse and Society 17(1): 5-27.

Patrona M (2009) 'A mess' and 'rows': evaluation in prime-time TV news discourse and the shaping of public opinion. Discourse and Communication 3(2): 173-194. 


\section{Kantara}

Patrona M (2011) Neutralism revisited: when journalists set new rules in political news discourse. In: Ekström M and Patrona M (eds) Talking Politics in Broadcast Media: Cross Cultural Perspectives on Political Interviewing, Journalism and Accountability. Amsterdam: Benjamins, pp. 157-176.

Romaniuk T (2013) Pursuing answers to questions in broadcast journalism. Research on Language and Social Interaction 46(2): 144-164.

Sacks H, Schegloff E and Jefferson G (1978) A simplest systematics for the organisation of turn taking for conversation. In: Schenkein J (ed) Studies in the Organisation of Conversational Interaction. New York: Academic Press, pp.7-55.

Schegloff E (1982) Discourse as an interactional achievement. Some uses of 'uh huh' and other things that come between sentences. In: Tannen D (ed) Analysing Discourse: Text and Talk. Washington, DC: Georgetown University Press, pp. 71-93.

Taylor PM (1992) Propaganda from Thucydides to Thatcher: Some Problems, Perspectives and Pitfalls. Address to the annual conference of the Social History Society of Great Britain. Available at: http://media.leeds.ac.uk/papers/vf01d900.html (accessed: 27 October 2015).

Thornborrow J (2001) 'Has it ever happened to you?' Talk shows as mediated performance. In: Tolson A (ed) TV Talk Shows: Discourse, Performance, Spectacle. Mahwah, NJ: Erlbaum, pp.117-138.

Tolson A (2012) 'You will need a miracle to win this election' (J. Paxman 2005): Interviewer assertiveness in UK general elections 1983-2010. Discourse, Context \& Media (1): $45-53$.

Warner M (2002) Publics and Counterpublics. Quarterly Journal of Speech 8(4): 413-425. Young RF and Lee J (2004) Identifying units in interaction: Reactive tokens in Korean and English conversations. Journal of Sociolinguistics 8(3): 380-407. 
Yngve VH (1970) On getting a word in edgewise. In: Papers from the $6^{\text {th }}$ Regional Meeting of the Chicago Linguistics Society, April 16-18. Chicago: Chicago Linguistics Society, pp. 567-578.

\section{Biographical note}

Argyro Kantara is a PhD candidate at the Centre for Language and Communication Research, Cardiff University, UK. Her PhD examines the use of hybrid interactional practices by journalists and politicians in one-on-one election campaign interviews and the role these might play in the knowledge producing practices of the transformed genre. 